\title{
Influence of norms of mineral fertilizers on the spike structure, on the grain of grain and straw, and also on the number of organic residues of winter powder
}

\author{
Dr.H.G.Muydinov*, Dr.I.E.Ruziev, Dr.Q.Juraeva \\ Andijan branch of TSAU
}

*Corresponding Authors: Dr.H.G.Muydinov, Andijan branch of TSAU

\begin{abstract}
The article describes the influence of top-dressing of winter wheat on its growth and development, productivity and agrochemical properties of the soil.
\end{abstract}

Keywords: winter wheat, mineral fertilizers, productivity, nitrogen, phosphorus, potassium

The data presented in our article were obtained as a result of research on the influence of various standards of mineral fertilizers on the growth, development and productivity of winter wheat are shown in table No. 1

It should be noted that we limited ourselves to the information obtained in 2010, because the information obtained over the years of research is very close to each other. In 1 - option when applying mineral fertilizers $\mathrm{N}-120 ; \mathrm{P} 2 \mathrm{O} 5-80 ; \mathrm{K} 2 \mathrm{O}-60 \mathrm{~kg}$ / ha the height of winter millet during the growing season was $97.8 \mathrm{~cm}$; the total number of stalks was $470 \mathrm{pcs} / \mathrm{m} 2$, the productive stalks were $350 \mathrm{pcs} / \mathrm{m} 2$, the spike length was $8.9 \mathrm{~cm}$, the number of grains in one spike was $35.2 \mathrm{pcs}$, the weight of grains per one ear of $1.50 \mathrm{~g}$, m weight 1000 grains of 35.8 grams

In the second embodiment, where the mineral fertilizers are extra-normal in the norm $\mathrm{N}-180$; P2O5$120 ; \mathrm{K} 2 \mathrm{O}$ - $90 \mathrm{~kg} / \mathrm{ha}$; the above indicators were $99.1 \mathrm{~cm}$, respectively; $475 \mathrm{pcs} / \mathrm{m} 2,360 \mathrm{pcs} / \mathrm{m} 2.9 .0$ $\mathrm{cm} ; 37.6$ pcs.; $1.51 \mathrm{~g}$ and $36.5 \mathrm{~g}$ with a difference with the first option respectively $1.3 ; 5 \mathrm{pcs} / \mathrm{m} 2 ; 10$ pcs $/ \mathrm{m} 2,0.1 \mathrm{~cm} ; 2.4$ pcs.; $0.001 \mathrm{~g}$ and $0.007 \mathrm{gr}$. However, in the second variant, the stems of winter wheat were no less than 2.3 from the beginning of development; $1.7 ; 2.5 \mathrm{~cm}$ higher than in the embodiment where the rate of mineral fertilizer application was $\mathrm{N}-120 ; \mathrm{P} 2 \mathrm{O} 5-80 ; \mathrm{K} 2 \mathrm{O}-60 \mathrm{~kg} / \mathrm{ha}$.

In the third embodiment, where mineral fertilizers are applied in the norm N -240; P2O5-160; K2O $120 \mathrm{~kg} / \mathrm{ha}$ at the end of the growing season, the height of the stems reached $100 \mathrm{~cm}$, the total number of stems $476 \mathrm{pcs} / \mathrm{m} 2$; the number of productive stems $361 \mathrm{pcs} / \mathrm{m} 2$; spike length $9.1 \mathrm{~cm}$; the number of grains on one ear 37.5 pcs. mass of grains on one ear $1.25 \mathrm{~g}$. Mass of 1000 grains $36.8 \mathrm{gr}$. and these figures are respectively $0.9 \mathrm{~cm}$ higher; 1.0 pcs.; $1.0 \mathrm{pcs} ; 0.1 \mathrm{~cm} ; 0.1 \mathrm{pcs} ; 0.01 \mathrm{~g}$ and $0.032 \mathrm{gr}$. than in the second option.

If we analyze the difference between these indicators, we can see the following difference in stem height between the first and second options is exactly $1.3 \mathrm{~cm}$, and between the second and third options this difference is $0.9 \mathrm{~cm}$. The difference between the options in the number of grains on one spike, which is the main indicator of winter wheat is $1.8 \mathrm{~cm}$ and $0.1 \mathrm{~cm}$, and for the mass of 1000 grains the difference was $0.7 \mathrm{~g}$. and 0.3 grams. So, the best indicators of growth and development were observed in the third option.

The differences between the options for the harvest of winter wheat were preserved over the years of research. In the embodiment where the rate of application of mineral fertilizers was N -180; P2O5-120; $\mathrm{K} 2 \mathrm{O}-90 \mathrm{~kg} / \mathrm{ha}$, yields, respectively, reached $68.0 ; 67.2 \mathrm{~m} 62.8 \mathrm{Ts} . / \mathrm{g}$, on average for 3 years at $66.0 \%$ $\mathrm{q} / \mathrm{ha}$. This means that in the $2 \mathrm{nd}$ variant of the experiment, $16.1 \mathrm{c} /$ ha was obtained more than from the 1st variant, where mineral fertilizers were applied according to the norm $\mathrm{N}-120 ; \mathrm{P} 2 \mathrm{O} 5-80 ; \mathrm{K} 2 \mathrm{O}$ $60 \mathrm{~kg} / \mathrm{ha}$. It should be noted that these yield increases in subsequent years of the study were $20.5 \mathrm{c} /$ ha and $15.2 \mathrm{c} / \mathrm{ha}$. 
Influence of norms of mineral fertilizers on the spike structure, on the grain of grain and straw, and also on the number of organic residues of winter powder

In the third embodiment, where the rate of application of mineral fertilizers was N -240; P2O5-160; $\mathrm{K} 2 \mathrm{O}-120 \mathrm{~kg} / \mathrm{ha}$, the grain yield increased to $70.1,69.2$ and $64.3 \mathrm{c} / \mathrm{g}$, respectively, over the years, on average for 3 years $67.8 \mathrm{c} / \mathrm{g}$, the yield increase is $17.9 \mathrm{c} / \mathrm{ha}$. This latter indicator is $1.8 \mathrm{c} /$ ha higher than in the second embodiment. So, in conditions of light gray-earth soils, in order to get a high yield of winter wheat, you need to make mineral fertilizers in the norm of $\mathrm{N}-180 ; \mathrm{P} 2 \mathrm{O} 5-120 ; \mathrm{K} 2 \mathrm{O}-90 \mathrm{~kg}$ / ha. Similar results were observed in experiments carried out on typical gray earth soils.

Table1.

\begin{tabular}{|c|c|c|c|c|c|c|c|c|c|c|c|c|c|}
\hline \multirow{2}{*}{ 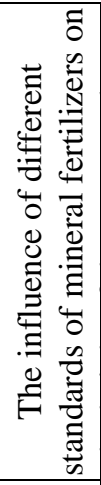 } & \multicolumn{3}{|c|}{$\begin{array}{c}\text { Mineral fertilizer } \\
\text { application rates kg } \\
\text { / ha }\end{array}$} & \multicolumn{4}{|c|}{ The height of the stems, $\mathrm{cm}$} & \multirow{2}{*}{ 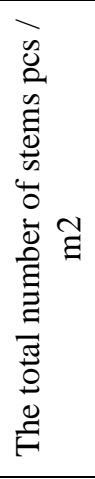 } & \multirow{2}{*}{ 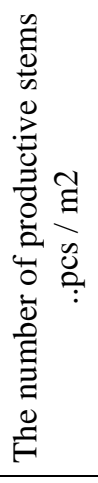 } & \multirow{2}{*}{ 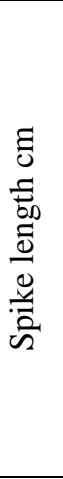 } & \multirow{2}{*}{ 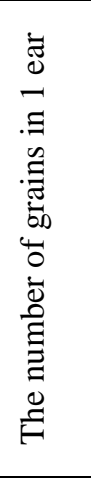 } & \multirow{2}{*}{ 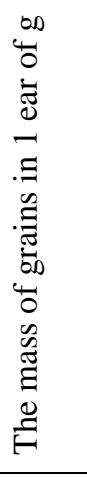 } & \multirow{2}{*}{ 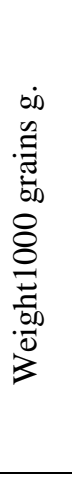 } \\
\hline & $\mathrm{N}$ & $\mathrm{P}_{2} \mathrm{O}_{5}$ & $\mathrm{~K}_{2} \mathrm{O}$ & 1.03 & 1.04 & 1.05 & 1.06 & & & & & & \\
\hline 1 & 120 & 80 & 60 & 9.8 & 48.1 & 77.6 & 97.8 & 470 & 350 & 8.9 & 35.2 & 1.50 & 35.8 \\
\hline 2 & 180 & 120 & 90 & 12.1 & 49.8 & 80.1 & 99.1 & 475 & 360 & 9.0 & 37.6 & 1.51 & 36.5 \\
\hline 3 & 240 & 160 & 120 & 12.0 & 50.0 & 81.2 & 100.0 & 476 & 361 & 9.1 & 37.5 & 1.52 & 36.8 \\
\hline
\end{tabular}

The results for straw yields for the options and for the year are very similar to the results of the grain harvest. Thus, in the first variant, for three years of research, the straw yield averaged $55.9 \mathrm{~kg} / \mathrm{ha}$, and in the second variant, $73.1 \mathrm{~kg} / \mathrm{ha}$ and in the third, $77.0 \mathrm{~kg} / \mathrm{ha}$. The straw yield increase in the 2nd variant was 17.2 centner / ha, and in the third variant higher - 21.1 centner / ha. The difference between the grain yield and the straw yield in the 2 nd embodiment is $1.1 \mathrm{c} / \mathrm{ha}$, and in the $3 \mathrm{rd}$ embodiment 3.2 $\mathrm{c} / \mathrm{ha}$. This shows that the applied mineral fertilizers are spent on increasing the grain mass of winter wheat. After harvesting grain and straw of winter wheat, samples are taken from each experimental field for options to determine the amount of total NPK in the biological residues of winter wheat in the soil. In the conditions of 2010, in the first embodiment, where the norm for applying mineral fertilizers is $\mathrm{N}-120$; $\mathrm{P} 2 \mathrm{O} 5-80 ; \mathrm{K} 2 \mathrm{O}-60 \mathrm{~kg} / \mathrm{ha}$, the sum of the remains of the stems was $13.7 \mathrm{~kg} / \mathrm{ha}$, and the remains of the roots $-25.1 \mathrm{~kg} / \mathrm{ha}$, a total of $38.8 \mathrm{~kg} / \mathrm{ha}$. If in the composition of the remains of the stems the amount of total nitrogen was $1.090 \%$, phosphorus $0.75 \%$ and potassium $1.060 \%$, then in the composition of the residues of the roots these indicators were $0.64 \%$, respectively; $0.2 \%$ and $0.79 \%$ of the total mass of residues of stems and roots $-1.73 \% ; 0.95 \%$ and $1.85 \%$.

In the second embodiment, where the rate of mineral fertilizer is $\mathrm{N}-180 ; \mathrm{P} 2 \mathrm{O} 5-120 ; \mathrm{K} 2 \mathrm{O}-90 \mathrm{~kg} / \mathrm{ha}$, the total amount of residues of roots and stems was $42.1 \mathrm{~kg} / \mathrm{ha}$, and the total amount of NPK in their composition, respectively, $1.98 ; 1.010 ; 1.885 \%$.

The difference with the first option for organic residues was $3.3 \mathrm{~kg} / \mathrm{ha}$, and for the total amount of NPK 0.150; 0.060 and $0.035 \%$.

In the third embodiment, where is the rate of mineral fertilizer application: N -240; P2O5-160; K2O $120 \mathrm{~kg} / \mathrm{ha}$, the total mass of organic residues amounted to $45.4 \mathrm{c} /$ ha, the total amount of NPK in their composition is $\mathrm{N}-180 ; \mathrm{P} 2 \mathrm{O} 5-120 ; \mathrm{K} 2 \mathrm{O}-90 \mathrm{~kg} / \mathrm{ha} \mathrm{N}-2.01 ; \mathrm{P}-1.05 ; \mathrm{K}-1.92 \%$. This is compared with the first option higher by $6.6 \mathrm{~kg} / \mathrm{ha}$, and $0.27 ; 0.1$ and $0.12 \%$, and in comparison with the second option, the leash is higher by $3.3 \mathrm{~kg} / \mathrm{ha}$ and by $0.03 ; 0.04$ and $0.035 \%$.

Table2. The influence of mineral fertilizer application rates on winter wheat grain yield ( $t /$ ha)

\begin{tabular}{|c|c|c|c|c|c|c|c|c|}
\hline \multirow{2}{*}{$\cdot \frac{\tilde{0}}{\tilde{0}}$} & \multicolumn{3}{|c|}{$\begin{array}{l}\text { Mineral application rates. fertilizers. kg } \\
\text { / ha }\end{array}$} & \multicolumn{3}{|l|}{ Years } & \multirow[t]{2}{*}{$\begin{array}{l}3 \text { years } \\
\text { average }\end{array}$} & \multirow[t]{2}{*}{ Increase } \\
\hline & $\mathrm{N}$ & $\mathrm{P}_{2} \mathrm{O}_{5}$ & $\mathrm{~K}_{2} \mathrm{O}$ & 2010 & 2011 & 2012 & & \\
\hline
\end{tabular}


Influence of norms of mineral fertilizers on the spike structure, on the grain of grain and straw, and also on the number of organic residues of winter powder

\begin{tabular}{|c|c|c|c|c|c|c|c|c|}
\hline 1 & 120 & 80 & 60 & 53,5 & 48,7 & 47,6 & 49,9 & - \\
\hline 2 & 180 & 120 & 90 & 68,0 & 67,2 & 62,8 & 66,0 & 16,1 \\
\hline 3 & 240 & 160 & 120 & 70,1 & 69,2 & 64,3 & 67,8 & 17,9 \\
\hline \multicolumn{9}{|c|}{ straw yield c / ha } \\
\hline 1 & 120 & 80 & 60 & 58,5 & 57,0 & 52,2 & 55,9 & - \\
\hline 2 & 180 & 120 & 90 & 75,0 & 74,8 & 69,5 & 73,1 & 17,2 \\
\hline 3 & 240 & 160 & 120 & 78,0 & 77,6 & 75,0 & 77,0 & 21,1 \\
\hline
\end{tabular}

This means that the difference in the indicators between the 1 st and 2 nd variants of the experiment is higher than the difference in the indicators between the 2 nd and 3rd variants, this shows that the optimal rate of applying mineral fertilizers for the growth and development of winter wheat is the norm of applying N -180; P2O5 -120; K2O - 90 kg / ha.

Table3. The influence of various norms of mineral fertilizers on the amount of organic residues and the total $N P K$ in their composition.

\begin{tabular}{|c|c|c|c|c|c|c|c|}
\hline \multirow[t]{2}{*}{ Options } & \multicolumn{3}{|c|}{ Norms of mineral fertilizers $\mathrm{kg} / \mathrm{ha}$} & \multicolumn{4}{|c|}{$\begin{array}{c}\text { The total amount of organic residues and NPK in } \\
\text { their composition }\end{array}$} \\
\hline & $\mathrm{N}$ & $\mathrm{P}_{2} \mathrm{O}_{5}$ & $\mathrm{~K}_{2} \mathrm{O}$ & ц/га & $\mathrm{N}$ & $\mathrm{P}$ & $\mathrm{K}$ \\
\hline 1 & 120 & 80 & 60 & 38,8 & 1,73 & 0,95 & 1,85 \\
\hline 2 & 180 & 120 & 90 & 42,1 & 1,98 & 1,01 & 1,885 \\
\hline 3 & 240 & 160 & 120 & 45,4 & 2,01 & 1,05 & 1,920 \\
\hline
\end{tabular}

Thus, according to the results of field studies with the introduction of mineral fertilizers in different doses (3 species) under winter wheatgrass varieties "Krasnodar - 99" in conditions of light gray-earth soils of the Andijan region showed that with an increase in doses of mineral fertilizers from $\mathrm{N}-120$; $\mathrm{P} 2 \mathrm{O} 5-80 ; \mathrm{K} 2 \mathrm{O}$ - $60 \mathrm{~kg} /$ ha to N-180; P2O5-120; K2O-90 kg / ha improved agrochemical properties for plant growth and development.

\section{LITERATURE}

[1] Дала тажрибаларини ўтказиш услублари.- Tashkent, 2007.180 p.

[2] Ибрагимов Н.М., Мирзаев Л.А., “Кузги буғдойда кўлланилган турли меъёрдаги азотли ўғитларнинг тупрокдаги нитрат шаклидаги миқдорига таъсири”.Republican Scientific and Practical Conference, collection, Tashkent, 2011. 75-77 pp

Citation: Dr.H.G.Muydinov, et.al., " Influence of norms of mineral fertilizers on the spike structure, on the grain of grain and straw, and also on the number of organic residues of winter powder" International Journal of Research Studies in Agricultural Sciences (IJRSAS), 2020; 6(11), pp. 1-3, https://doi.org/10.20431/24546224.0611001

Copyright: () 2020 Authors. This is an open-access article distributed under the terms of the Creative Commons Attribution License, which permits unrestricted use, distribution, and reproduction in any medium, provided the original author and source are credited. 